\title{
PENGARUH MODEL PEMBELAJARAN BERBASIS MASALAH DENGAN METODE EKSPERIMEN TERHADAP HASIL BELAJAR FISIKA SISWA KELAS X SMAN 1 GUNUNGSARI KABUPATEN LOMBOK BARAT TAHUN PELAJARAN 2014/2015
}

\author{
Azmi Aziz', Joni Rokhmat ${ }^{2}$, Kosim ${ }^{2}$ \\ 1) Program Studi Pendidika Fisika \\ 2) Program Studi Pendidika Fisika FKIP \\ Universitas Mataram \\ Mataram Indonesia \\ Email: azmiaziz96@yahoo.com
}

\begin{abstract}
This research aims to find out the effect of problem based learning model with eksperiment method on the student's results of learning physics of grade X SMAN 1 Gunungsari regency west Lombok in academic year 2014/2015. This research is a quasi eksperiment with pretest posttest control group design. The population of this research is students of grade X SMAN 1 Gunungsari, with cluster random sampling technique was obtained students of grade X5 as the experiment group and students of grade X2 as control group. The result of learning is analized by using t-test polled varians, was obtained 9,25 for thint and 1,99 for ttable with significant $5 \%$. Because thint $>\mathrm{t}_{\text {table }}$, then Ho will be rejected and Ha will be accepted. So can be concluded that available effect of problem based learning model with eksperiment method on the student's results of learning physics of grade X SMAN 1 Gunungsari regency west Lombok in academic year 2014/2015.
\end{abstract}

Keywords: Problem based learning, experiment method, results of learning physic.

\section{PENDAhUluan}

Pada hakekatnya Ilmu Pengetahuan Alam (IPA) merupakan suatu produk, proses, dan sikap. Fisika merupakan bagian dari IPA maka dapat diambil persepsi bahwa hakikat fisika sama dengan hakikat IPA. Hasil-hasil penemuan dari berbagai kegiatan penyelidikan dikumpulkan dan disusun secara sistematik menjadi sebuah kumpulan pengetahuan yang disebut sebagai produk. Kumpulan pengetahuan itu dapat berupa fakta, konsep, prinsip, hukum, rumus, teori, atau model. Pemahaman fisika sebagai suatu proses adalah pemahaman mengenai bagaimana informasi ilmiah dalam fisika diperoleh, diuji, dan divalidasikan. Proses penemuan, pengamatan, pengukuran, dan penyelidikan ilmiah yang dilakukan memerlukan proses mental dan sikap yang berasal dari pemikiran yang tercermin dalam rasa ingin mengetahui dan rasa penasaran mereka yang besar, diiringi dengan rasa percaya, sikap objektif, jujur, dan terbuka, serta mau mendengarkan pendapat orang lain. Sikap-sikap itulah yang kemudian memaknai hakekat fisika sebagai sikap [1].

Fisika adalah salah satu cabang ilmu pengetahuan yang terus mengalami perkembangan. Seiring dengan perkembangannya, masalah- masalah dalam pembelajaran fisika dicari solusi dan perbaikannya. Salah satu diantara masalah tersebut yakni terkait dengan pembelajaran fisika di kelas. Masalah yang sering disoroti adalah rendahnnya pemahaman siswa pada materi fisika yang diajarkan [2]. Terdapat banyak faktor yang terlibat di dalam proses belajar mengajar, baik dari siswa yang belajar maupun guru yang mengajar. Faktor yang berasal dari siswa sendiri adalah bahan pelajaran, ketekunan, keuletan, kerajinan, dan kedisiplinan dalam belajar. Sedangkan faktor dari guru adalah materi pelajaran dan model pembelajaran yang digunakan.

Berdasarkan hasil observasi awal yang dilakukan di SMAN 1 Gunungsari saat menerapkan kurikulum 2013 pada kelas X MIA (Matematika dan Ilmu Alam), nilai rata-rata fisika siswa masih banyak di bawah Kriteria Ketuntasan Minimum (KKM), yakni 75. Hasil belajar fisika yang rendah ini menandakan kurangnya pemahaman siswa terhadap materi fisika yang diajarkan. Pembelajaran fisika masih cenderung didominasi guru (teacher center), sehingga siswa menjadi pasif dalam pembelajaran. Siswa hanya memperhatikan penjelasan guru dan berdiskusi tentang materi pelajaran. 
Pembelajaran fisika sebaiknya dirancang untuk memfasilitasi siswa agar dalam beraktifitas bersentuhan langsung dengan objek konkrit yang terkait. Konsep-konsep, hukum-hukum, dan teoriteori tidak seharusnya diajarkan kepada siswa sebagai pengetahuan yang sudah jadi dan tinggal diingat saja. Melainkan memberikan kesempatan kepada siswa untuk berinteraksi langsung dengan objek konkrit yang sedang dipelajari sehingga siswa belajar bagaimana mendapatkan pengetahuan. Guru menjalankan tugasnya sebagai fasilitator dan membimbing siswa dalam penelusuran masalah terhadap fenomena yang diamati, kemudian mencari penyelesaian masalah, menganalisis masalah, dan membuat kesimpulan dari fenomena yang diamati sehingga dapat membangun pengetahuan fisika siswa yang akhirnya dapat meningkatkan hasil belajar fisika siswa.

Fisika sebagai produk, proses, dan sikap dalam pembelajarannya harus mempertimbangkan metode pembelajaran yang efektif dan efisien yaitu salah satunya melalui kegiatan eksperimen. Kegiatan eksperimen dalam pembelajaran fisika dapat mengaktifkan siswa saat proses belajar mengajar. Selain itu, memberikan kesempatan kepada siswa untuk mengembangkan sejumlah keterampilan dan meningkatkan kualitas belajar siswa sehingga pembelajaran fisika menjadi lebih bermakna sehingga hasil belajar fisika siswa meningkat. Berdasarkan uraian di atas, maka peneliti tertarik untuk melakukan penelitian berjudul "Pengaruh Model Pembelajaran Berbasis Masalah dengan Metode Eksperimen terhadap Hasil Belajar Fisika Siswa Kelas X SMAN 1 Gunungsari Kabupaten Lombok Barat Tahun Pelajaran 2014/2015".

\section{Tinjauan Pustaka}

\section{A. Model Pembelajaran Berbasis Masalah}

Model pembelajaran berbasis masalah merupakan sebuah model pembelajaran yang menyediakan pengalaman autentik yang mendorong siswa untuk belajar aktif, mengkonstruksi pengetahuan, dan mengintegrasikan konteks belajar di sekolah dan belajar di kehidupan nyata secara alamiah. Pembelajaran yang dikaitkan dengan kehidupan sehari-hari siswa secara ilmiah akan menuntut siswa berpikir dan mendapatkan hasil belajar yang alamiah pula. Berdasarkan pandangan tersebut, Model Pembelajaran Berbasis Masalah selanjutnya berkembang menjadi sebuah model pembelajaran yang berbasiskan masalah sebagai hal yang muncul pertama kali pada saat proses pembelajaran. Model pembelajaran ini mengharuskan siswa senantiasa mengembangkan kemampuan berpikir, kemampuan memecahkan masalah, dan kemampuan melaksanakan penelitian [3].

Model pembelajaran berbasis masalah didefinisikan sebagai rangkaian aktivitas pembelajaran yang menekankan pada proses penyelesaian masalah secara ilmiah. Model pembelajaran berbasis masalah mengusung gagasan utama bahwa tujuan pembelajaran dapat tercapai jika kegiatan pendidikan dipusatkan pada tugastugas atau permasalahan yang autentik, relevan, dan dipresentasikan dalam suatu konteks. Dengan kata lain, tujuan utama pendidikan adalah memecahkan masalah-masalah kehidupan. Konsekuensinya, bangunan pengetahuan maupun teori yang diajarkan tidak cukup hanya dihafal dan dipahami, melainkan harus dikaitkan dengan realita yang terjadi dan digunakan untuk menyelesaikan masalah-masalah yang ada [4]. Masalah yang dikemukakan kepada siswa harus dapat membangkitkan pemahaman siswa terhadap masalah, kesadaran adanya kesenjangan, pengetahuan, tujuan keinginan memecahkan masalah, dan persepsi bahwa mereka mampu memecahkan masalah tersebut [5].

\section{B. Metode Eksperimen}

Metode eksperimen adalah salah satu cara mengajar yang memfasilitasi siswa melakukan percobaan tentang sesuatu hal, mengamati prosesnya, serta menuliskan hasil percobaannya. Dalam metode ini, hasil percobaan dipresentasikan di kelas dan dievaluasi oleh guru. Penggunaan metode ini mempunyai tujuan agar siswa mampu mencari dan menemukan sendiri berbagai jawaban atas masalah-masalah yang dihadapi dengan melaksanakan percobaan sendiri. Siswa juga menjadi terlatih dalam berpikir ilmiah dan menemukan bukti kebenaran dari teori tentang sesuatu yang sedang dipelajarinya [6].

Sementara itu, metode eksperimen juga didefinisikan sebagai cara penyajian pelajaran yang memfasilitasi siswa melakukan percobaan dengan mengalami dan membuktikan sendiri sesuatu yang dipelajari. Karenanya, siswa dituntut untuk mengalami sendiri, mencari kebenaran, hukum, atau dalil, serta menarik kesimpulan atas proses yang dialaminya [7]. 
Berdasarkan kedua definisi di atas, maka peneliti menyimpulkan bahwa metode eksperimen merupakan metode mengajar yang memberikan pengalaman langsung kepada siswa untuk melakukan suatu percobaan guna membuktikan sesuatu yang sedang dipelajarinya.

\section{Metode Penelitian}

Jenis penelitian ini yaitu penelitian kuasi eksperimen. Penelitian kuasi eksperimen merupakan suatu cara untuk mencari hubungan sebab akibat antara dua variabel atau lebih yang sengaja ditimbulkan tetapi tidak dapat berfungsi sepenuhnya untuk mengontrol variabel-variabel luar yang mempengaruhi pelaksanaan eksperimen karena sulit mendapatkan kelompok kontrol yang digunakan untuk penelitian [8]. Penelitian ini dilaksanakan dari Oktober 2014 sampai dengan April 2015 bertempat di SMAN 1 Gunungsari kabupaten Lombok Barat. Desain penelitian menggunakan Pre-Test Post-Test Control Group Design. Populasi dalam penelitian ini yaitu seluruh siswa kelas X SMAN 1 Gunungsari yang terbagi dalam 9 kelas. Teknik pengambilan sampel menggunakan cluster random sampling sehingga diperoleh kelas X5 sebagai kelas eksperimen dan kelas X2 sebagai kelas kontrol. Kelas eksperimen diberi perlakuan model pembelajaran berbasis masalah dengan metode eksperimen, sedangkan kelas kontrol diberi pembelajaran konvensional.

Pengumpulan data dalam penelitian ini dilakukan dengan metode tes menggunakan tes pilihan ganda sebanyak 25 soal yang telah dipilih sesuai kriteria analisis uji instrumen, meliputi analisis validitas, reliabilitas, taraf kesukaran, dan daya beda soal. Tes dilakukan sebanyak dua kali yakni tes awal (pre-test) dan tes akhir (post-test). Pre-test dilakukan sebelum kegiatan pembelajaran untuk mengetahui kemampuan awal siswa terhadap materi pelajaran. Oleh karena itu, pada data hasil pre-test dilakukan uji homogenitas menggunakan Uji Varians (Uji F). Sementara itu, post-test dimaksudkan untuk mengetahui hasil belajar siswa terhadap materi pelajaran setelah kegiatan pembelajaran. Analisis data hasil post-test meliputi uji normalitas (Chi Kuadrat), homogenitas (Uji Varians), dan hipotesis. Uji normalitas digunakan untuk mengetahui normalitas data guna menentukan uji statistik dalam uji hipotesis. Uji homogenitas untuk uji lanjut statistik parametrik yang digunakan jika data terdistribusi normal. Uji hipotesis dilakukan untuk mengetahui pengaruh model pembelajaran berbasis masalah dengan metode eksperimen terhadap hasil belajar fisika siswa.

\section{HaSil dan PEMbahasan}

Hasil penelitian berupa deskripsi data pre-test dan post-test. Hasil pre-test kelas eksperimen dan kontrol pada materi kalor dapat dilihat dalam tabel 1 berikut.

Tabel 1 Hasil Pre-Test Kelas Eksperimen dan Kontrol

\begin{tabular}{|c|c|c|}
\hline \multirow[b]{2}{*}{ Komponen } & \multicolumn{2}{|c|}{ Hasil Pre-Test } \\
\hline & $\begin{array}{c}\text { Kelas } \\
\text { Eksperimen }\end{array}$ & $\begin{array}{c}\text { Kelas } \\
\text { Kontrol }\end{array}$ \\
\hline Jumlah siswa & 35 & 34 \\
\hline Nilai tertinggi & 60 & 60 \\
\hline Nilai Terendah & 20 & 16 \\
\hline Rata-rata & 42,63 & 44,47 \\
\hline Standar Deviasi & 10,36 & 10,84 \\
\hline $\begin{array}{l}\text { Hasil Uji } \\
\text { Homogenitas }\end{array}$ & \multicolumn{2}{|c|}{ Homogen } \\
\hline
\end{tabular}

Berdasarkan data pada tabel 1, terlihat nilai ratarata kelas eksperimen $(42,63)$ lebih rendah dibandingkan kelas kontrol $(44,47)$. Nilai rata-rata kedua kelas di atas masih berkategori rendah karena di bawah KKM. Selain itu, kedua kelas homogen. Hal ini berarti kedua kelas memiliki kemampuam awal yang sama. Hasil post-test kelas eksperimen dan kontrol pada materi kalor dapat dilihat dalam tabel 2 berikut.

Tabel 2 Hasil Post-Test Kelas Eksperimen dan Kontrol

\begin{tabular}{|c|c|c|}
\hline \multirow[b]{2}{*}{ Komponen } & \multicolumn{2}{|c|}{ Hasil Pre-Test } \\
\hline & $\begin{array}{c}\text { Kelas } \\
\text { Eksperimen }\end{array}$ & $\begin{array}{c}\text { Kelas } \\
\text { Kontrol }\end{array}$ \\
\hline Jumlah siswa & 35 & 34 \\
\hline Nilai tertinggi & 96 & 72 \\
\hline Nilai Terendah & 56 & 32 \\
\hline Rata-rata & 75,42 & 54,23 \\
\hline $\begin{array}{l}\text { Standar } \\
\text { Deviasi }\end{array}$ & 9,87 & 9,14 \\
\hline $\begin{array}{l}\text { Hasil Uji } \\
\text { Normalitas }\end{array}$ & Normal & Normal \\
\hline $\begin{array}{l}\text { Hasil Uji } \\
\text { Homogenitas }\end{array}$ & \multicolumn{2}{|c|}{ Homogen } \\
\hline $\begin{array}{l}\text { Uji } t \text {-test } \\
\text { polled varians }\end{array}$ & \multicolumn{2}{|c|}{$\begin{array}{l}t_{\text {hitung }}>t_{\text {tabel }}, \mathrm{H}_{\mathrm{o}} \text { ditolak dan } \\
\mathrm{H}_{\mathrm{a}} \text { diterima }\end{array}$} \\
\hline
\end{tabular}

Hasil post-test pada tabel $2 \mathrm{di}$ atas, memperlihatkan bahwa nilai rata-rata kelas eksperimen $(75,42)$ lebih tinggi dari kelas kontrol 
$(54,23)$. Hasil ini menunjukkan bahwa kedua kelas sama-sama mengalami peningkatan.Namun, peningkatan yang dialami kedua kelas cenderung kontras. Hasil post-test kemudian dihitung normalitas datanya menggunakan rumus chikuadrat, diperoleh bahwa data kedua kelas adalah normal. Hal ini berarti uji hipotesis menggunakan statistik parametrik. Hasil perhitungan uji homogenitas diperoleh bahwa kedua kelas adalah homogen, berarti statistik parametrik yang digunakan yaitu, t-test polled varians pada taraf signifikan $5 \%$. Uji hipotesis menggunakan t-test polled varians diperoleh $t_{\text {hitung }}=9,25$, lebih besar dari $t_{\text {tabel }}=1,99$. Hal ini berarti terdapat pengaruh model pembelajaran berbasis masalah dengan metode eksperimen terhadap hasil belajar fisika siswa kelas X SMAN 1 Gunungsari kabupaten Lombok Barat tahun pelajaran 2014/2015.

Kelas eksperimen yang diberi perlakuan model pembelajaran berbasis masalah dengan metode eksperimen lebih aktif dibandingkan kelas kontrol yang diberi pembelajaran konvensional. Siswa pada kelas eksperimen aktif dalam mengumpulkan data secara lengkap guna memecahkan masalah yang dihadapai. Pada awal pembelajaran siswa diberi masalah dalam lembar kegiatan siswa (LKS) terkait materi kalor yang diajarkan. Masalah yang dikemukakan kepada siswa tersebut dapat membangkitkan pemahaman siswa terhadap masalah, kesadaran adanya kesenjangan, pengetahuan, tujuan keinginan memecahkan masalah, dan persepsi bahwa mereka mampu memecahkan masalah. Oleh karena itu, penyajian masalah di awal pembelajaran dapat mendorong siswa untuk belajar aktif. Terkait masalah yang harus dipecahkan dalam pembelajaran tersebut, siswa dituntut untuk membuat hipotesis (jawaban sementara) sesuai dengan kemampuan awal yang dimiliki. Siswa kemudian dituntut untuk membuktikan hipotesis melalui kegiatan eksperimen.

Kegiatan eksperimen menuntut siswa dapat terlibat aktif dan bersentuhan langsung dengan objek konkrit dalam pembelajaran. Konsep-konsep, hukum-hukum, dan teori-teori mengenai kalor diperoleh siswa melalui proses pemecahan masalah dengan eksperimen. Selama kegiatan eksperimen berlangsung, siswa dapat mengamati kesesuaian antara hipotesis dengan fakta yang terjadi terkait eksperimen yang sedang dilaksanakan. Hal ini dapat memperkuat pengetahuan siswa mengenai materi kalor yang sedang dipelajari. Apabila hipotesis yang dibuat siswa terkait masalah sudah sesuai dengan fakta yang terjadi selama proses eksperimen, maka hal ini dapat memperkuat pemahaman siswa mengenai materi kalor. Sebaliknya, apabila hipotesis yang dibuat oleh siswa belum sesuai dengan fakta yang terjadi selama proses eksperimen, maka hal ini dapat memberikan pemahaman yang benar kepada siswa. Pemahaman yang diperoleh melalui kegiatan eksperimen ini dapat mengkonstruksi pengetahuan siswa, karena siswa secara aktif terlibat dalam pembelajaran untuk memecahkan masalah.

Data yang diperoleh siswa melalui kegiatan eksperimen selanjutnya diolah untuk menjawab pertanyaan-pertanyaan yang telah tersedia dalam lembar kegiatan siswa (LKS). Pertanyaanpertanyaan tersebut telah dirancang supaya siswa diarahkan pada kesimpulan akhir yang benar. Terkait pertanyaan ini siswa dituntut untuk berdiskusi dengan teman kelompok untuk mencari jawaban berdasarkan data yang diperoleh, sehingga siswa dapat bertukar informasi. Hasil eksperimen dan diskusi disampaikan oleh salah satu kelompok di depan kelas dan ditanggapi oleh kelompok lain. Penyampaian hasil eksperimen ini memberikan kesempatan kepada siswa untuk saling bertukar informasi antar kelompok. Selain itu, kekurangan masing-masing kelompok terkait materi kalor dapat diketahui. Guru/peneliti dapat memberikan kesimpulan akhir yang benar dan sama pada setiap kelompok. Oleh karena itu, siswa mendapatkan pengetahuan terkait masalah yang disajikan di awal pembelajaran, sehingga siswa dapat menjawab permasalah tersebut.

Uraian di atas sesuai dengan teori yang menyatakan bahwa, pembelajaran berbasis masalah memberikan kesempatan kepada siswa untuk mengumpulkan dan menganalisis data secara lengkap dalam memecahkan masalah yang dihadapai. Karenanya, siswa dapat membangun sendiri konsep yang dipelajarinya, serta dapat mengembangkan keterampilan berpikirnya berdasarkan pemecahan masalah. Fokus model pembelajaran ini adalah penyelesaian masalah terkait materi pembelajaran, bukan bagaimana guru menyampaikan materi pembelajaran. Dalam pembelajaran berbasis masalah, siswa bekerjasama dalam kelompok sehingga terjadi pertukaran pikiran yang dapat membangun penyelesaian masalah [9]. Selain itu, model pembelajaran 
berbasis masalah dengan metode eksperimen menyediakan pengalaman autentik yang mendorong siswa untuk belajar aktif, mengkonstruksi pengetahuan, dan mengintegrasi konteks belajar di sekolah dan belajar di kehidupan nyata secara ilmiah [3].

\section{Penutup}

Pada taraf signifikan 5\% terdapat pengaruh model pembelajaran berbasis masalah dengan metode eksperimen terhadap hasil belajar fisika siswa kelas X SMAN 1 Gunungsari Kabupaten Lombok Barat tahun pelajaran 2014/2015.

Model pembelajaran berbasis masalah dengan metode eksperimen dapat dijadikan sebagai alternatif model pembelajaran yang dapat diterapkan untuk mengaktifkan siswa, sehingga hasil belajar kognisi siswa meningkat. Penerapan model pembelajaran berbasis masalah dengan metode eksperimen harus memperhatikan beberapa hal, yaitu:

a. Alokasi waktu diatur sebaik mungkin sehingga tiap tahapan pembelajaran dapat berlangsung secara maksimal;

b. Alat dan bahan eksperimen disiapkan sebaikbaiknya.

c. Menguji kelayakan pakai alat dan bahan yang akan digunakan dalam eksperimen.

\section{UCAPAN TERIMA KASIH}

Terima kasih penulis sampaikan kepada Bapak Dr. H. Wildan, M.Pd., Dr. Drs. Karnan, M.Si., Dr. Ahmad Haryono, S.Si., M.Pd., serta semua pihak yang telah membantu penelitian ini.

\section{REFERENSI}

[1] Hikmawati, dan Gunada, I.W. 2013. Kajian Fisika SMA. Mataram: FKIP Universitas Mataram.

[2] Astuti, N.S.P. 2012. Pengaruh Model Pembelajaran POE(Predict-Observe-Explain) terhadap Hasil Belajar Fisika Siswa Kelas VII SMP Negeri 1 Praya Tengah Tahun Ajaran 2012/2013. Skripsi Jurusan Pendidikan Fisika FKIP UNRAM: Tidak diterbitkan.

[3] Abidin, Y. 2014. Desain Pembelajaran dalam Konteks Kurikulum 2014. Bandung. PT Refika Aditama.

[4] Suyadi. 2013. Strategi Pembelajaran Pendidikan Berkarakter. Bandung: PT Remaja Rosdakarya.
[5] Rusman, 2011. Model-Model Pembelajaran. Bandung: Rajawali Pers.

[6] Roestiyah, N.K. 2012. Strategi Belajar Mengajar. Jakarta: Rineka Cipta.

[7] Djamarah.S.B, dan Zain A. 2013. Strategi Belajar Mengajar. Jakarta: PT Rineka Cipta.

[8] Sugiyono. 2014. Metode Penelitian Pendidikan, Pendekatan Kuantitatif, Kualitatif, dan R\&D. Jakarta:Alfabeta.

[9] Huda, M. 2013. Model-Model Pengajaran dan Pembelajaran Isu-Isu Metodis dan Pragmatis. Yogyakarta: Pustaka Pelajar.

\section{Biografi PENUlis}

Azmi Aziz, S.Pd., lahir di dusun Sidemen desa Lembahsari kabupaten Lombok Barat 19 November 1993. Penulis telah menyelesaikan pendidikan di SDN 2 Lembahsari, SMPN 1 Gunungsari, dan SMAN 1 Gunungsari. Kemudian melanjutkan studinya di FKIP Universitas Mataram pada Program Studi Pendidikan Fisika (Alumni 2011, Lulus juni 2015). 